\title{
Review paper
}

\section{Influence of Non-governmental Organizations on Corporate Sustainability Practices. Towards an Institutional-legitimacy Perspective}

\section{Lamin B. Ceesay}

University of Verona, Graduate School of legal and Economic Sciences, Santa Marta Building, Via Cantarane, 24, 37129 Verona, Italy.

* Correspondence: laminb.ceesay@univr.it (phone: +39 3512781239)

\begin{abstract}
There is growing adoption of corporate sustainability practice in both for-profit and not-for-profit organizations. This proliferation is largely due to the increasing concerns for social, environmental and economic factors in which we assume shared responsibility. Despite the growing attention of researchers and practitioners, several corporations failed to meet their sustainability responsibilities. Several reasons could be associated to this phenomenon such as lack of regulatory mechanism, accountability, etc. This review, however, seeks to examine how nongovernmental organizations (henceforth, NGOs) influence corporate sustainability adoption (i.e. sustainability reporting). In the review of prior research, we leveraged the institutional-legitimacy and corporate governance theories. The findings suggest that NGOs have greater potential in sustainability discourse through two salient actions, namely (1) collaborative partnership, and (2) confrontational tactics. While the former promotes stakeholder involvement in corporate decision making through dialogue, joint-projects on CSR, sustainability reporting, the latter, however, is the last resort involving "naming and shaming" corporations for poor social and environmental performance through public and social media. The objective of such action is to cause reputational damage to businesses. Finally, it is also observed that crucial to NGO power and influence is the collaboration with government and civil society organizations in the fight for environmental sustainability and accountability.
\end{abstract}

Keywords: Sustainability reporting, NGOs, stakeholder theory, Africa, NGO participation

\section{Introduction}

There is growing adoption of corporate sustainability practice in both for-profit and not-for-profit organizations. This proliferation is largely due to the increasing concerns for social, environmental and economic factors in which we assume shared responsibility (Burrit and Schaltegger, 2010; O'Dwyer et al., 2010). For-profit corporation, sustainability practice comes mainly in the form of corporate social responsibilities (CRS) performance and reporting (see Ahmed and Karpik, 1989; Janggu et al., 2014). Oftentimes, these adoptions are not voluntary, but due to regulatory pressures such as the General Reporting Initiative (GRI) (Hahn and Kühnen, 2013), pressure from environmental activists, and NGOs activism (Guay and Doh, 2006; Guay et al., 2017; Crespy and Miller, 2011), industry best practices or managerial concern towards non-managerial 
stakeholders (Li et al., 2018; Thijssens, et al., 2016; Janggu et al., 2014) and the new form of collaboration and alliances between NGOs and corporations (Arenas et al., 2009) have intensified these practices.

Studies debate whether corporate governance systems and practices should continue to converge on the Anglo-American shareholder-value-oriented model or the stakeholder model (Krenn, 2016; Brammer, Jackson and Matten, 2012). Describing the latter as the "best" alternative model that is inclusive towards a more equitable and wealthy world in which the natural environment and our cultural are preserved for generations to come (Dyllick and Hockerts, 2002). Further, Michelon and Parbonetti (2012) argue in addition to full disclosure of financial, social and environmental information, stakeholder perspective is a more appropriate model that ensure dialogue between a company and its essential non-managerial stakeholders. This offers companies the ability to "provide information on a company's activities that legitimise their behaviour to educate and inform, and change perceptions and expectations" of broader stakeholders (Michelon and Parbonetti, 2012). Stakeholder perspective further helps to keep in balance increasing shareholder value and the satisfaction of non-managerial stakeholders (Cramer-Montes, 2017).

On the issues of sustainable development, NGOs continues to dominate the discourse for social equity and justice for the social wellbeing. While NGOs continue to strengthen their efforts to raise environmental awareness through public awareness campaigns, their role in corporate sustainability practices of corporations remain low, thus, relegating social and environmental considerations in the hands of corporations. Although NGOs' believe that environmentally conscious public will eventually force companies to improve their environmental performance (Asfaw et al., 2017) through different mechanisms such as sustainability reporting and stakeholder engagement (Aras and Crowther, 2008), little progress have been made in that front.

Despite the growing adoption of corporate sustainability programs in the for-profit companies, several organizations such as NGOs, and government corporations seem to be far behind in their efforts to promoting sustainability practices (Hahn and Kühnen, 2013) and Africa and other developing economies remind far behind in such discourse compared to the US and Europe (Kuzey and Uyar, 2017). Plethora of studies was conducted in the developed economies make it almost impossible to generalize the findings of these studies for emerging countries, as their underlying legal or institutional background differs from those in developed countries. For example, developing countries have wider gaps in enforcement in terms of environmental protection laws or human rights compared to developed countries (Kuzey and Uyar, 2017). Moreover, stakeholder (i.e. civil organizations, media, consumers, NGOs) influence in emerging countries might be less influential than in developed countries (Kuzey and Uyar, 2017). Guay and Doh (2006), however, attribute the growth of sustainability to different "institutional structures and political legacies" in the USA and the EU.

Therefore, to solidify the application of stakeholder view, this study leverages the institutional-legitimacy perspective to exemplify the powers and influence of NGOs towards corporate sustainability practice. This contribution will pave a strong way for research on NGO in the areas of corporate sustainability practices. Based on the review of distinguished research in several fields, this conceptual review discusses some of the salient roles of NGOs. Using their powers and influence, NGOs may have two strategies or tactics to promote their involvement in sustainability discourse: "collaborative partnership" and "confrontational tactics." The former 
promotes stakeholder involvement in corporate decision making through dialogue, joint-projects on CSR, sustainability reporting, while the latter, mostly as last resort, use "naming and shaming" of poor social and environmental performing companies using public and social media attracting global consumer boycott, class actions - leading to loss of business and higher reputational risk. Crucial to NGO power and influence is the collaboration of government and civil society organizations in the fight for a more socially responsible way of business through accountability and transparency. We are seeing the rise of NGOs playing fundamental roles in the world, particularly, in community developments in Africa. Their activities pertain sustainable development discourse through fundraising, collaboration with MNCs, advocating for human rights, and campaigns for social and environmental conservation. In that sense, NGOs have potential to engage corporations in strengthening sustainability programs.

This review paper is organized accordingly; first with a brief introduction presented above, second, a theoretical review, followed by the last section on discussion and conclusion.

\section{Theoretical background}

\subsection{Stakeholder theory}

Advocates of the Anglo-Saxion model argue that firms must maximize shareholder returns in order to meet the demand of its broader, non-managerial stakeholders (Brammer, Jackson and Matten, 2012; Krenn, 2016). Because ownership is highly concentrated, board members serve as proxies of the shareholders leaving no room for the representation of external stakeholders under the Anglo-Saxon model (Li et al., 2018; Laplume, Litz and Sonpar, 2008; Brammer, Jackson and Matten, 2012). Consequently, Freeman (1994) defines a stakeholder as follows...'stakeholder is any group or individual who can affect or is affected by the achievement of an organization's purpose..." Stakeholder theory raise fundamental questions over the obligation organizations towards all its stakeholders in terms of their response to three key questions, namely (1) what is the responsibility of the corporation in an ideal society in its value-creating activity, (2) what desirable changes to the laws and institutions of societies need to be modified to reflect ethical ideals of a just society and (3) what are the moral responsibilities of managers in their dealing with shareholders and stakeholders within the context of those laws and institutions? (Freeman, 1994). To sum, firm's obligation (moral and/or legal) towards stakeholders is not limited to "respect" but also their "full participation in the decision making process" of the business as traditionally recognised in the "stakeholder economies" like Germany and Japan (Freeman, 1994; Hendry, 2001; Freeman, et al., 2004).

Accommodating stakeholders in a firm's decision-making process raises eyebrows among critics that it is a very demanding practice (e.g. Jensen, 2001; Hendry, 2001). Despite the critics of stakeholder theory, firms begin to recognise that stakeholder-friendly companies are those that are high performing and more sustainable (Hendry, 2001; Jensen, 2001). The theory does a good job by explaining and directing managerial (Laplume, Litz and Sonpar, 2008; Freeman, et al., 2004), value-seeking or value-maximizing behaviour towards the market (Jensen, 2001) which thus makes a good business sense (Freeman, 1994). The theory gives managers greater capability to deal with stakeholders through "financial rewards, language and action" to show that they value the relationship and wish to work to advance their common interest (Freeman, et al., 2004). Therefore, managers must develop relationships, inspire their stakeholders, and create communities where everyone strives to deliver the value the firm promises. 


\subsection{Institutional-legitimacy perspective}

Leveraging the institutional theory perspective of governance, corporations can unify the differences in a shareholder-stakeholder debate (Krenn, 2016). The theory observes the holistic view, rather than an isolationist perspective of market forces (Freeman, 1994), "social embeddedness, and shared communities" (Brammer, Jackson and Matten, 2012) and cultural forces shaping corporate governance at the national and firm levels (Krenn, 2016). Pressure from within and outside the organizations determines its "inertia and stability" that is critical survival and marketplace success (DiMaggio and Powell, 1983).

Pressure from the firm's external context can impose "coercive, normative or mimetic" influence to which it must conform to acquire its legitimacy (DiMaggio and Powell, 1983). Suchman (1995) defines "Legitimacy is a generalized perception or assumption that the actions of an entity are desirable, proper, or appropriate within some socially constructed system of norms, values, beliefs, and definitions." Organizations change to meet the demand of the society through "isomorphism" (DiMaggio and Powell, 1983) where they derived their "legitimacy" by conforming to pressures from their environment. Suchman (1995) demonstrates two reasons why corporations seek legitimacy namely, (1) to pursue "continuity and credibility" and (2) to gain acceptance and "active or passive support" from the conduct of its business. These pressures may arise from critical exchange partners, government, labor unions, the public, regulatory agencies, capital providers and various professional groups (Brammer, Jackson and Matten, 2012; DiMaggio and Powell, 1983; Krenn, 2016). Pressure from non-managerial stakeholders often threatens the firm's financial performance. Hence, leveraging institutional-legitimacy perspective, firms can recognize stakeholders in terms of their "unique identities, positions and interests" that influence their business operations (Roe, 2004). Because competition extends beyond a firm's idiosyncratic resources and customers, the "power and legitimacy, for social and economic fitness" it commands is crucial to its survival (DiMaggio and Powell, 1983; Krenn, 2016).

Normative isomorphism results from both formal and informal pressures exerted on the organization based on the expectations in the society within which organizations function (DiMaggio and Walter,1983). Coercive isomorphism is derived from legal and political influence confronting the operation of the business in society (Suchman, 1995; DiMaggio and Powell, 1983) in the form of requirements for good governance and legal regulations such as financial reporting, financing etc. Mimic institutional isomorphism- Socially-responsible organizations learn from their competitors and market leaders on "industry best practices" aim at minimizing risks of uncertainty (DiMaggio and Powell, 1983). Organizations may model themselves on other organizations. The growing popularity of sustainability from regulators, activists, governments, and industry best practice, require firms to adopt new institutional [re]configurations to deliver diverse stakeholder needs. For example, corporate disclosure or sustainability reporting policies begin to be integrated into the firm's corporate strategy as a mean to legitimize corporate activities (Michelon and Parbonetti, 2012). Because corporate sustainability lies in "business system" or "organizational field" within which firms operate, scholars argue that institutional theory is an appreciate theoretical lens for the study of sustainability in corporate governance (Guay and Doh, 2006; Brammer, Jackson and Matten, 2012). Moreover, corporate sustainability disclosure is part of the dialogue between a company and its stakeholders which provides information on a company's activities that "legitimize its behaviour, educate and inform, and change perceptions and expectations." (Michelon and 
Parbonetti, 2012). Understanding the stakeholders based on their influence and interest is crucial to the due diligence and determines the way in which corporations relate to the marketplace participants.

\subsection{Non-Governmental Organisations "NGOs"}

Several groups of organizations operate under the umbrella of "non-governmental organizations", "NGOs", third sector or the "civil society organizations." Moreover, Arenas, Lozano and Albareda (2009) have identified two categories of NGOs, namely, "social purpose NGOs (or Club NGOs)" and "membership organisations." Social purpose NGOs include environmental groups, human rights organisations, organisations that fight against poverty and underdevelopment or provide medical assistance in emergencies. Club NGOs get their legitimacy from performing public interest works, accountability to different parties and compliance with legal regulations. Membership organisations, on the other hand, obtain their legitimacy from a democratic election process of membership.

Moreover, Sandhu and Arora (2012) found Indians NGOs mostly involve in a wide range of causes related to the environment such climate change, air pollution, deforestation, ozone layer depletion, waste management, biodiversity and land use, energy, conservation, environmental degradation, and land degradation. Further, In Africa, we have seen NGO efforts in environmental sustainability or CSR by addressing climate change, waste management, pollution, biodiversity and land use (Asfaw et al., 2017).

While NGOs managers face "stereotypes and ambivalent roles" in corporate governance practices, some constituents perceive them as "advocates, judges, fundraisers, etc." (Winston, 2002; Arenas et al., 2009). The diversity and multiplicity of NGOs make it difficult for companies and other stakeholders to know who they represent and what their role is. Some NGOs are indirectly representing the consumers of a company's products, others the views of their own members, workers in developing countries or simply their own organisational interests (Asfaw, Botes and Mengesha, 2017). Despite the critical role of NGOs in Africa, there is still a lack of uniform action and collaboration between NGOs, governments, and corporations. Often, they tend to engage in "reacting to damage control caused by "unsustainable corporate practices (Asfaw et al., 2017).

Traditionally, NGOs were interested mainly in getting public and private funds to develop their social work or to promote environmental conservation. But today, NGOs acquired a new function beyond their traditional mission aimed at changing the economic and political conditions that lie at the root of social and environmental problems (Asfaw et al., 2017).

\subsection{Source of NGO legitimacy}

Suchman (1995, p. 574) defines legitimacy as "a generalized perception or assumption that the actions of an entity are desirable, proper, or appropriate within some socially constructed system of norms, values, beliefs, and definitions." NGOs get their legitimacy from their mission in terms of their involvement in "social impact or cause-related" activities of sustainable development (Asfaw et al., 2017). "Social legitimacy" of NGOs is multifaceted such that it allows endorsement of their behaviour by its salient stakeholders (e.g., government and resource partners) and environmental pressure on how the firms use and manage resources (Marano and Tashman, 2012). NGOs seem to have better credibility than other organizations and become even more relevant to corporations in the context of corporate social responsibility (CSR). However, the greater power and influence of MNCs in Africa over the marketplaces, the society, and on government policy, has challenged the 
new paradigm of MNC/NGOs partnership into the debate (Winston, 2002). On the basis of CSR, Marano and Tashman (2012) found that MNE/NGO partnerships are mean to consolidate the mutual legitimacy of the two parties for success and survival. This new form of partnership continues to allow NGOs to engage MNCs through dialogue and joint-project financing, corporate sponsorship.

Shell organization suffered a global legitimacy crisis after it was alleged for severe environmental degradation in the Niger Delta in Nigeria. This crisis caused Shell company loss of millions of dollars of its financiers and global consumer boycotts of shell gas stations (Marano and Tashman, 2012). To remedy this reputational and legitimacy crisis, Shell company partnered with NGOs like the Living Earth Foundation "to help develop and implement new strategic initiatives for community engagement and reinvestment" towards more philanthropic efforts (Marano and Tashman, 2012).

Critics argue that NGOs may lose legitimacy for their inadequate commitment to sustainability disclosure for which they require for-profit organizations to do (Cramer-Montes, 2017). If NGOs promote the course of social and environmental disclosure, will enhance their desire to have a more legitimate voice in the process of corporate governance and the dialogue about sustainable development (Cramer-Montes, 2017). This new role of NGOs has the potential to engage corporations, even further, on sustainability disclosure, assurance through effective non-managerial stakeholder engagement. To bring about a more accountable corporate governance practices such as CSR, sustainability reporting, NGOs must press for a more stakeholder partnership to combat corporate governance mis practices relating to social and environmental performances.

\subsection{NGOs strategies for promoting sustainability discourse}

Kolk (2008) note that NGOs call for transparency from two different angles: accountability requirement in the context of corporate governance over ethical aspects; and sustainability reporting that has broadened from the environment only to social and financial issues. Although, NGOs are the most active voices in criticizing companies for their insufficient CSR, and, they face lots of "stereotypes and ambivalent roles" as "advocates, judges, and fundraisers." (Arenas et al., 2009). To remain relevant in their discourse for sustainable environmental performance, NGOs must strengthen public environmental awareness because the environmentally conscious public will eventually force companies to improve their environmental performance (Asfaw et al., 2017) through different mechanisms such as sustainability reporting and stakeholder engagement. Avenues like public platforms and social media campaigns will enhance their public-environmental awareness efforts.

Working with relevant government institutions, public servants and other interest groups would foster promulgation of "soft laws" on sustainability reporting (Winston, 2002). Unfortunately, African countries continue to show a slow and low reporting regulation, and lower level of public engagement in corporate sustainability initiatives (Kolk, 2008). NGOs can push for more transparency and accountability in corporate environmental performance. To meet the challenging stakeholder demand, accountability relating to sustainability reporting allows companies to address a multitude of audiences over information relating to environmental performance (Kolk, 2008). Winston, (2002), advised that the NGO-led CSR movement must now move the agenda from "voluntary adoption to "soft law" approaches enforcing rigorous national 
and international enforcement regimes and mobilize support from informed consumers, concerned government officials, and progressive companies.

Studies argue that if corporations integrate sustainability practices with corporate governance, information symmetry for both the company and its non-managerial stakeholder will be enhanced (Kolk, 2008). Hence when all stakeholders' (including shareholders') information requests are satisfied, and that different (or sometimes conflicting) demands are catered for.

NGOs push for sustainability reports as a signal of a company's long-term commitment towards economic, social, and environmental performance (Kuzey and Uyar, 2017). Despite the limited studies on non-governmental organizations (NGOs) in terms of sustainability programs, we begin to see the joint-collaborative efforts of for-profit and not-for-profit firms towards issues relating to sustainable development. The growing awareness of sustainability matters has been reflected in the activist and advocate roles play by the NGOs (Nobanee and Ellili, 2016). Around the 90 s, we begin to see NGOs at the forefront of sustainability campaign leading to their growth in number, power and influence.

Guay and Doh (2006) argue that the national legal system and social concern shape the conduct of NGOs in corporate strategy. Unlike the African continent, Europe and the US have well-organized NGOs representation with great influence and involvement in sustainability and CSR programme of corporations (Guay and Doh, 2006). Authors further claim that "different governance structures" and "political legacies" in EU and the US guarantee NGO influence in policy-making process and governance of sustainability issues such as global warming, and pricing of anti-viral pharmaceuticals in developing countries (Guay and Doh, 2006).

In the fight against less inclusion of non-managerial stakeholders, NGOs continue to advocate for a participative governance of sustainable development (Cramer-Montes, 2017). Recently, NGOs involvement in sustainability affairs has intensified environmental reporting, with value relevant information and stakeholder engagement. This, however, has exerted pressure on corporations thus promoting good governance and accountability (Brammer, Jackson and Matten, 2012). NGOs intensify their collaboration with relevant governments and organizations for sustainability policy: advising that sustainability programs must be institutionalized as part of the organization structure with the recruitment and training, and the establishment of a sustainability department and committee (e.g. Kuzey and Uyar, 2017; Kolk, 2003).

Sometimes NGOs use power and influence to enforce disclosing sustainability information by corporations. NGOs persuasion strategy motivate firms to desire for transparency, enhance reputation (Marano and Tashman, 2012; Hahn and Kühnen, 2013), promote community relations, and legitimizing their activities (Kuzey and Uyar, 2017). Just like for-profit firms, size of NGOs could have a positive effect on the adoption and extent of sustainability reporting. For-profit organizations, larger corporations often cause greater social and environmental impacts hence become more visible, and face greater stakeholder scrutiny and pressure (Hahn and Kühnen, 2013) for sustainability concerns. Bigger NGOs depict stronger membership and power to influence corporate sustainability decisions.

\subsection{NGOs and stakeholder engagement}

The role of NGOs has the potential to engage corporations even further on sustainability disclosure through effective non-managerial stakeholder engagement. Stakeholder engagement extends to a complex network relationship of global suppliers, NGOs, distributors, public servants 
and others. The study of NGOs perception in Spain found that mutual understanding between NGOs and trade unions influence the firms' CSR initiatives (Arenas, Lozano and Albareda, 2009) hence a need for a broader stakeholder involvement exacerbate legitimacy of NGOs. Therefore, through stakeholder involvement programs, Corporations would be able to understand stakeholder perception, belief and worldview, particularly NGOs to promote corporate sustainability programs such as CSR and environmental disclosure (Arenas, Lozano and Albareda, 2009). The study further posits that "distinction among the power, legitimacy and threats of by specific stakeholder group require managers to allocate priorities to competing stakeholder (Arenas, Lozano and Albareda, 2009). While some groups of stakeholders pose a less financial or reputational risk, the corporation must seek to views and demands of others like NGOs through an appropriate level of engagement and dialogue.

Recently, there is a growing use of stakeholder engagement in firms' sustainability or CSR programme. The main question concerning stakeholder management is the identification and prioritization of stakeholders (Laplume, Litz and Sonpar, 2008) Meanwhile, CSR is more tightly linked to formal institutions of stakeholder participation or state intervention in other advanced economies (Brammer, et al., 2012). The participation of stakeholders (stakeholder engagement) brings together a rich sense of community for discussions and negotiations on a range of social and economic issues (O'Dwyer, Unerman and Bradley, 2005). NGOs-corporations partnership, if managed well, can enhance a more productive dialogue that promotes "freedom of participation, equal opportunity, and transparency" (Arenas, Lozano and Albareda, 2009). Such partnership brings companies and NGOs into a conversations, consultations, and debates relating to CSR and other corporate governance programs. Companies should further promote these through sustainability reporting and NGOs engagement in the discourse (Guay and Doh, 2006).

According to Winston (2002), tactics for NGOs dealing with corporations as "engagers" draw corporations into dialogue on the basis of adopting ethical practices and code of conduct, while "confronters" on the other hand, assume that corporations will only listen when their financial interests are threatened. Moreover, Marano and Tashman (2012) classified the interaction between Corporations and NGOs into three, namely: the "philanthropic" stage, which is often passive with less resource sharing where corporations are the major sources of funding for NGO projects; the "transactional" stage is the moderately intensive form of relationship in the form of cause-related marketing, corporate sponsorship, etc.; and "strategic alliance" stage which is highly intensive based on mutual resource-dependency, and execution of projects. Collaboration between NGOs and Corporations pertains the two parties working together to foster improved environmental conservation and quality of life for the communities (Asfaw, Botes and Mengesha, 2017). Moreover, strategic for of partnership between NGOs-Corporation allows them "to elaborate commonly agreed on certification schemes, promote and design CSR standards, sustainability management, and reporting processes (Arenas et al., 2009; Asfaw et al., 2017).

Proposition 1: the more NGOs use "collaborative" tactics, corporations are more likely to adopt

effective sustainability practices to improve their reputation and legitimacy.

When partnerships fail to yield meaningful benefits, NGOs resort to a more drastic, confrontational "naming and shaming" for bad environmental performance (Winston, 2002). Although non-managerial stakeholders, particularly NGOs, do not have any financial stake, their "confrontational strategy" can have a severe negative impact on the financial performance of the 
(Asfaw, Botes and Mengesha, 2017; Winston, 2002). Despite their resolve for more dialogue and collaboration, many corporation-NGO partnerships continue as rather "adversarial" such that NGOs intensify the voice of "disgruntled" civil society group (Marano and Tashman, 2012). NGOs could use key stakeholders to sign petitions, boycott and protest companies for poor environmental performance leading to loss of credibility and reputation (Asfaw et al., 2017). Mostly, the result of confrontational mode seeks "to demonstrate more to accountability, dialogue, and remorse on the part of corporations for negative social impact caused, and thus promote positive attitude towards social performance (Marano and Tashman, 2012), and improved government regulations, and behaviour of public servants (Asfaw et al., 2017).

Some examples of include the NGOs-business confrontation in the form of anti-corporation campaigns largely due to the demand of Ogoni people over oil spills in Nigeria, those against Shell over the North Sea Oil Platform Brent Spar, the ones against Nike over child labour and GAP for the working conditions in suppliers' factories. This rising anti-corporation campaign has made businesses to change their policies due to powers and influence of environmental NGOs. In fact, through intense legal battle and campaigns spearheaded by NGOs over the 1970s' Brent Spar chemical explosions at Flixborough and Seveso, the European Seveso Directive has now become a core part of European environmental protection. Furthermore, Winston (2002) highlights eight different tactics that various NGOs have employed in their relations with different companies to adopt CSR:

- the dialogue aimed at promoting the adoption of voluntary codes of conduct - the pure CSR approach

- advocacy of social accounting and independent verification schemes

- the filing of shareholder resolutions

- documentation of abuses and moral shaming

- calls for boycotts of company products or divestment of stock

- advocacy of selective purchasing laws

- advocacy of government-imposed standards

- litigation seeking punitive damages

Proposition 2: when NGOs use the threat of "confrontational tactics, corporations are more likely to adopt effective sustainability practices due to the threat of reprisal from NGOs.

Although there is less research on the partnership between NGOs and government and political parties, this new form of relationship could help strengthen NGO's guess for accountability and transparency in corporate sustainability discourse. NGOs fostering more civil society and government partnerships the course of sustainable development has shown significant improvements in Romania, thus complementing the government's development effort (Matei and Apostu, 2014). Furthermore, Harrison (2017) observes the relationship between NGOs and political leaders in India, and results show that the "high dependency of NGOs on government funding creates pressure for professionalization and bureaucratization" on NGOs. While "NGO-political connection" may enhance the former to attract funds, volunteers and its image, caution must be taken such that this connection does not adversely affect the independence and advocacy role of NGOs (Harrison, 2017).

However, NGOs can judiciously leverage political connection to strengthen NGO voice in sustainability policy and implementation. To foster sustainable development policy dialogue 
between NGO-civil society and government, (Matei and Apostu, 2014) recognizes the following policy dimensions: "Good Governance" based on sound social, environmental policies, and accountability to broader society; "Regulations" designed to help, implement social, environmental performance; "Taxation policies" as incentive for good performance, and conformance to best practices; "Coordination" by relevant stakeholders, including NGOs; and "official support" to civil society and NGOs to strengthen activities without undermining "autonomy and independence" through funding, contracts, and training opportunities.

Proposition 3: strong mutual commitment in the partnership between NGOs and civil society and the government will strengthen more NGO influence and power over the adoption of sustainability reporting in corporations.

Social and environmental disclosure is just one aspect of corporate sustainability practice. Just like for-profit firms, NGOs must ensure there is the credibility of information on sustainability reports. Credible reports provide value relevance to users of sustainability reports on many technical environmental and social indicators. Such reports should be verifiable to ensure assurance through independent investigation (Kuzey and Uyar, 2017). The increased adoption of sustainability practices and reporting is associated with tightened regulation (Hahn and Kühnen, 2013). Therefore, NGOs partnerships with relevant stakeholders, such as civil society and governments would allow for effective monitoring to ensure value relevant non-financial disclosure.

Proposition 4: higher NGO power and influence can induce the adoption of quality and value-relevance of sustainability reports by corporations.

Engaging corporations for relevant disclosure of firms could embrace its image associated with transparency, the value of information symmetry for debt financing (Nobanee and Ellili, 2016), and legitimizing its business with the government and its broader non-managerial stakeholders.

\section{Discussion and Conclusion}

\subsection{Discussion}

The purpose of the literature review is to assess the influence of NGO power on corporate sustainability practices through the lens of institutional-legitimacy perspective. It aims to create a direction for future research. It is noteworthy that the role of NGOs in the course of corporate sustainability remain highly under-explored, particularly, empirically (Asfaw, Botes and Mengesha, 2017). A plethora of research acknowledges the importance of stakeholder participation in corporate governance practice (e.g. Manetti, 2011; Jensen, 2001). When a corporation engages its non-managerial stakeholders, it helps increase their corporate visibility because of the frequent direct interaction with the public. Because sustainability reporting improves the firm's transparency and accountability, stakeholder trust is enhanced, and corporate legitimacy is improved (Hahn and Kühnen, 2013; O’Dwyer, Owen and Unerman, 2011).

This review observed that NGOs must establish a partnership with relevant stakeholders in order to foster their strives for improved corporate governance sustainability practices. Four main types of collaboration are needed to bring about the improved social and environmental performance among corporations. Each constituent offers unique functional roles towards NGOs' advocacy for an improved sustainable social and environmental performance: first, NGO-civil society partnership. Civil society partnership with NGOs allows for more voice in the call for social 
impact performance (Bank and Reuben, 2002). In developing countries, MNCs have a bigger influence in marketplace, society and governance policy, thus more civil society participation signifies a new form of "revolution" with great bargaining power and influence for transparency and accountability in corporate governance practices (Crespy and Miller, 2011).

Second, NGO-government collaboration. NGOs' participation in sustainable policy design, implementation and monitoring have been very limited in developing countries particularly for African countries. African economies lack the legal instruments and regulations to encourage sustainability practices of MNCs. Even in the presence of these laws, they are often not enforced, perhaps adequately (de Villiers and van Staden, 2006). Hence, the role played by NGOs provides a much more government partnership towards sustainability disclosure in corporate governance. NGO-government partnership requires the full participation of NGOs in regulatory policy design that relates to sustainability development. This form of the partnership will allow NGOs to exercise their advocacy and autonomy while drafting policies that affect minorities, future generations and local communities. Not only for policy-partnership, but government support to NGOs in terms contract of "special projects" financing (Marano and Tashman, 2012), tax waivers, social and environmental impact assessments of corporations are crucial to this partnership.

Finally, NGO-corporations partnership. Corporations are primarily driven by the business interest for higher returns to their shareholders with the rather lesser interest of the welfare of people and communities they operate. This business interest, for the most part, supersedes the wellbeing of the communities. Thus, special interest groups like NGOs must pursue accountability and transparency of corporations. Corporations feel that society does not keep them accountable for their actions, ordinary citizens, children, minorities are most affected by their actions. In support of proponents of stakeholder theory, NGOs must engage corporations for more inclusion of non-managerial stakeholders in the activities of corporations that affect the social fabric of the very societies they operate (O'Dwyer, Unerman and Bradley, 2005). However, NGOs can publicly "name and shame" those corporations for inaction or poor social and environmental performance (Asfaw, Botes and Mengesha, 2017; Winston, 2002). Such media exposure can be in the number of news articles relating to a company's sustainability performance reporting increases reputational risks associated with bad press for poor performance. Although dialogue form of consultation is encouraged but more drastic, confrontational tactics like a boycott, are required to promote a responsible corporate sustainability program. These corporations act swiftly when they know their financial resources are at risk from such "confrontational" actions. Further study can test empirically the above propositions. A thorough case study of specific NGOs would add value relevance to the understanding of NGOs power and influence.

\subsection{Conclusion}

There is a limited study on the influence of NGOs on corporate sustainability practices, particularly, in the empirical stream. However, recently we are seeing the rise of NGOs playing fundamental roles in the world, particularly, in the community developments in Africa. Their activities pertain sustainable development discourse through fundraising, collaboration with MNCs, advocating for human rights, and campaigns for social and environmental conservation. Therefore, the aim of this paper is to create an insight into the power and influence of NGOs in the course for corporate sustainability adoption (i.e. sustainability reporting). Leveraging on the institutional-legitimacy perspective, this study looks at how the participation of relevant stakeholder 
such as NGOs in corporate sustainability may influence social and environmental performance of corporations (Suchman, 1995; Brammer, Jackson and Matten, 2012b).

Using their powers and influence, NGOs may have two strategies or tactics to promote their involvement in sustainability discourse: "collaborative partnership" and "confrontational tactics." The former promotes stakeholder involvement in corporate decision making through dialogue, joint-projects on CSR, sustainability reporting, while the latter, mostly as last resort, use "naming and shaming" of poor social and environmental performing companies using public and social media attracting global consumer boycott, class actions - leading to loss of business and higher reputational risk. Crucial to NGO power and influence is the collaboration of government and civil society organizations in the fight for a more socially responsible way of business through accountability and transparency. The government must work closely with NGO in the areas of regulatory policy design and performance measurement, while civil society would help strengthen the call for prosperous social and environmental impact accountability of corporations.

\section{References}

[1] R. L. Burritt and S. Schaltegger, Sustainability accounting and reporting: Fad or trend?, vol. 23, no. 7. 2010.

[2] R. Hahn and M. Kühnen, "Determinants of sustainability reporting: a review of results, trends, theory, and opportunities in an expanding field of research," J. Clean. Prod. J., vol. 59, pp. 5-21, 2013.

[3] A. Belkaoui and P. G. Karpik, "Determinants of the Corporate Decision to Disclose Social Information," Accounting, Audit. Account. Journal, vol. 2, no. 1, 1989.

[4] T. Janggu, D. Faizah, M. M. Zain, and Y. Sawani, “Does Good Corporate Governance Lead to Better Sustainability Reporting? An Analysis Using Structural Equation Modeling," ProcediaSoc. Behav. Sci., vol. 145, pp. 138-145, 2014.

[5] R. Hahn and M. Kühnen, "Determinants of sustainability reporting: A review of results, trends, theory, and opportunities in an expanding field of research," J. Clean. Prod., vol. 59, pp. 5-21, 2013.

[6] T. R. Guay and J. P. Doh, "Corporate Social Responsibility, Public Policy, and NGO Activism in Europe and the United States: An Institutional-Stakeholder Perspective Jonathan P," J. Manag. Stud., vol. 43, no. 1, pp. 47-73, 2006.

[7] A. Kocmanová, J. H. Hřebíček, and M. Dočekalová, "Corporate Governance And Sustainability," Econ. Manag., vol. 16, no. 3, pp. 1822-6515, 2011.

[8] C. T. Crespy and V. V. Miller, "Sustainability reporting: A comparative study of NGOs and MNCs," Corp. Soc. Responsib. Environ. Manag., vol. 18, no. 5, pp. 275-284, 2011.

[9] Y. Li, M. Gong, X. Y. Zhang, and L. Koh, "The impact of environmental, social, and governance disclosure on firm value: The role of CEO power," Br. Account. Rev., vol. 50, no. 1, pp. 60-75, 2018.

[10] T. Thijssens, L. Bollen, and H. Hassink, "Managing sustainability reporting: many ways to publish exemplary reports," J. Clean. Prod., vol. 136, pp. 86-101, 2016.

[11] G. Aras and D. Crowther, "Governance and sustainability: An investigation into the relationship between corporate governance and corporate sustainability," Manag. Decis., vol. 46, no. 3, pp. 433-448, 2008.

[12] M. Krenn, "Convergence and divergence in corporate governance: An integrative 
institutional theory perspective," Manag. Res. Rev., vol. 39, no. 11, pp. 1447-1471, 2016.

[13] S. Brammer, G. Jackson, and D. Matten, "Convergence and divergence in corporate governance An integrative institutional theory perspective," Am. Sociol. Rev., vol. 39, no. 11, pp. 1447-1471, 2012.

[14] T. Dyllick and K. Hockerts, "Beyond the business case for corporate sustainability," Bus. Strateg. Environ., vol. 11, no. 2, pp. 130-141, 2002.

[15] G. Michelon and A. Parbonetti, "The effect of corporate governance on sustainability disclosure," J. Manag. Gov., vol. 16, no. 3, pp. 477-509, 2012.

[16] J. Cramer-Montes, Sustainability. 2017.

[17] C. Kuzey and A. Uyar, "Determinants of sustainability reporting and its impact on firm value: Evidence from the emerging market of Turkey," J. Clean. Prod., vol. 143, pp. 27-39, 2017.

[18] M. Krenn, "Convergence and divergence in corporate governance An integrative institutional theory perspective," Manag. Res. Rev., vol. 39, no. 11, pp. 1447-1471, 2016.

[19] S. Brammer, G. Jackson, and D. Matten, "Corporate Social Responsibility and institutional theory : new perspectives on private governance," Socio-Economic Rev., vol. 10, pp. 3-28, 2012.

[20] A. O. Laplume, R. A. Litz, and K. Sonpar, "Stakeholder Theory: Reviewing a Theory That Moves Us," J. Manage., vol. 34, no. 6, pp. 1152-1189, 2008.

[21] R. E. Freeman, "The Politics of Stakeholder Theory : Some Future Directions," Cambridge Univ. Press, vol. 4, no. 4, pp. 409-421, 1994.

[22] J. Hendry, "Missing the Target: Normative Stakeholder Theory and the Corporate Governance Debate," Cambridge Univ. Press, vol. 11, no. 1, pp. 159-176, 2001.

[23] M. C. Jensen, "Value Maximization, Stakeholder Theory, and the Corporate Objective Function," J. Appl. Corp. Financ., vol. 14, no. 3, 2001.

[24] R. E. Freeman, A. C. Wicks, and B. Parmar, "Revisited "Stakeholder Theory and "The Corporate Objective Revisited,'” Organ. Sci., vol. 15:3, no. June 2019, pp. 364-369, 2004.

[25] P. J. DiMaggio and W. W. Powell, “The Iron Cage Revisited : Institutional Isomorphism and Collective Rationality in Organizational Fields," Am. Sociol. Rev., vol. 48, no. 2, pp. 147-160, 1983.

[26] M. Suchman, "Managing Legitimacy: Strategic and Institutional Approaches," Acad. Manag. Rev., vol. 20, no. 3, pp. 571-610, 1995.

[27] M. J. Roe, "The Institutions of Corporate Governance," in John M. Olin Center for Law, Economics and Business, Harvard Law School, 2004.

[28] D. Arenas, J. M. Lozano, and L. Albareda, "The Role of NGOs in CSR: Mutual Perceptions Among Stakeholders," J. Bus. Ethics, vol. 88, no. 1, pp. 175-197, 2009.

[29] T. S. Asfaw, V. Botes, and L. G. Mengesha, "The role of NGOs in corporate environmental responsibility practice: evidence from Ethiopia," Int. J. Corp. Soc. Responsib., vol. 2, no. 2, 2017.

[30] V. Marano and P. Tashman, "MNE/NGO partnerships and the legitimacy of the firm," Int. Bus. Rev., vol. 21, no. 6, pp. 1122-1130, 2012.

[31] A. Kolk, "Sustainability, Accountability and Corporate Governance: Exploring Multinationals' Reporting Practices," Bus. Strateg. Environ., vol. 18, pp. 1-15, 2008.

[32] H. Nobanee and N. Ellili, "Corporate sustainability disclosure in annual reports: Evidence from UAE banks: Islamic versus conventional," Renew. Sustain. Energy Rev., vol. 55, pp. 1336-1341, 2016. 
[33] J. Cramer-Montes, "Sustainability: A New Path to Corporate and NGO Collaborations," Stanford Soc. Innov. Rev., 2017.

[34] B. O'Dwyer, J. Unerman, and J. Bradley, Perceptions on the emergence and future development of corporate social disclosure in Ireland: Engaging the voices of non-governmental organisations, vol. 18, no. 1. 2005.

[35] M. Winston, "NGO Strategies for Promoting Corporate Social Responsibility," Ethics Int. Aff., vol. 16, no. 2, 2002.

[36] A. Matei and D. - C. Apostu, "The Relationship between the State and the Non Governmental Organizations," Procedia - Soc. Behav. Sci., vol. 143, pp. 847-851, 2014.

[37] T. Harrison, "NGOs and Personal Politics: The Relationship between NGOs and political leaders in West Bengal, India," World Dev., vol. 98, pp. 485-496, 2017.

[38] G. Manetti, "The Quality of Stakeholder Engagement in Sustainability Reporting: Empirical Evidence and Critical Points," Corp. Soc. Responsib. Environ. Manag., vol. 18, no. 3, pp. 110-122, 2011.

[39] B. O'Dwyer, D. Owen, and J. Unerman, "Seeking legitimacy for new assurance forms: The case of assurance on sustainability reporting," Accounting, Organ. Soc., vol. 36, pp. 31-52, 2011.

[40] W. Bank and W. Reuben, "Nongovernmental Organizations Show Their Growing Power The New York Times," New York Times, 2002.

[41] C. de Villiers and C. J. van Staden, "Can less environmental disclosure have a legitimising effect? Evidence from Africa," Accounting, Organ. Soc., vol. 31, no. 8, pp. 763-781, 2006.

Funding: This research received no external funding. 